\title{
Philosophies of adult education as practiced by agricultural education teachers in Pennsylvania, West Virginia, and Virginia
}

Crystal R. Buckingham

West Virginia University

Follow this and additional works at: https://researchrepository.wvu.edu/etd

\section{Recommended Citation}

Buckingham, Crystal R., "Philosophies of adult education as practiced by agricultural education teachers in Pennsylvania, West Virginia, and Virginia" (2000). Graduate Theses, Dissertations, and Problem Reports. 1063.

https://researchrepository.wvu.edu/etd/1063

This Thesis is protected by copyright and/or related rights. It has been brought to you by the The Research Repository @ WVU with permission from the rights-holder(s). You are free to use this Thesis in any way that is permitted by the copyright and related rights legislation that applies to your use. For other uses you must obtain permission from the rights-holder(s) directly, unless additional rights are indicated by a Creative Commons license in the record and/ or on the work itself. This Thesis has been accepted for inclusion in WVU Graduate Theses, Dissertations, and Problem Reports collection by an authorized administrator of The Research Repository @ WVU. For more information, please contact researchrepository@mail.wvu.edu. 


\title{
Crystal R. Buckingham
}

\author{
Thesis submitted to the \\ College of Agriculture, Forestry, and Consumer Sciences \\ at West Virginia University \\ in partial fulfillment of the requirements \\ for the degree of \\ Master of Science \\ in \\ Agricultural Education
}

\author{
Stacy A. Gartin, Ph.D., Chair \\ Layle D. Lawrence, Ph.D. \\ Kerry S. Odell, Ph.D. \\ Harry N. Boone, Ph.D. \\ Department of Resource Management
}

Morgantown, West Virginia

2000

Keywords: Agriculture, Philosophy, PAEI, Adult Education 


\begin{abstract}
Philosophies of Adult Education as Practiced by Agricultural Education Teachers in Pennsylvania, West Virginia, and Virginia
\end{abstract}

Crystal R. Buckingham

The purpose of this study was to increase understanding of adult education philosophies as practiced by Pennsylvania, West Virginia, and Virginia secondary school agriculture teachers.

A Philosophy of Adult Education Inventory (PAEI) and researcher-created demographic sheet was sent to a sample of agriculture teachers in the tri-state area $(n=314)$. Descriptive data were analyzed using the Statistical Package for Social Sciences for Windows (SPSS).

Frequencies, means, and correlational and multivariate analyses were used to describe and analyze the research results.

It was shown that there is a slight relationship between adult education preparation and the five philosophies. The Humanist philosophy is statistically significant when comparing the states of Pennsylvania and West Virginia. Educator's payment for teaching adult classes is significant when compared to the Progressive orientation. The Liberal and Behaviorist philosophies were shown to have a very strong association as do the Progressive and Behaviorist philosophies. 


\section{AKNOWLEDGEMENTS}

First, I would like to thank the members of my committee. Dr. Gary Wingenbach who was instrumental in getting this project started. Without his advice and help this thesis would still be incomplete. Thank you for being my chairperson and putting up with the endless questions.

To Dr. Stacy Gartin thanks for jumping in mid-way through and taking over as chairperson of my committee. Your help and friendship was greatly appreciated. Thank you for the pep talks throughout my education. They helped me to hang in there when I was ready to give up.

To Dr. Layle Lawrence, the I want to express my sincere thanks for the chat on statistics and setting up the tables in Chapter IV. It made much more sense after you explained it.

To Dr. Kerry Odell, for being part of my committee on such short notice. I appreciate the time you gave up to be part of my committee.

To Dr. Harry Boone, who was a recent and greatly appreciated admission to the committee. Thank you for the help and advice on the last minute additions to the manuscript.

I give sincere thanks to my parents, Charles and Donna, for allowing me the financial means to complete my education at WVU and the gentle prodding to get this thesis completed. Without their support and love, I would not be who or where I am today.

To my brothers Jeff and Kevin and my sister-in-law Deborah, thanks for lending me support and the offers to proofread. I appreciate you taking time out of your busy schedules to help.

Special thanks to Roger for being there and helping with all the little secretarial jobs. Your pep talks and input were a great help and kept me sane. Your love and help was appreciated more than could ever be expressed. 
TABLE OF CONTENTS

TITLE PAGE

ABSTRACT ii

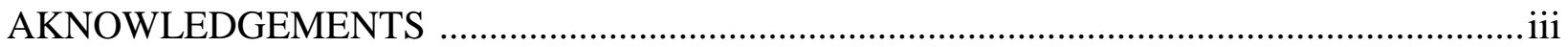

TABLE OF CONTENTS ………….....................................................................................

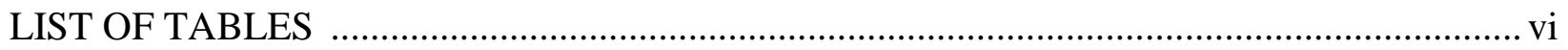

CHAPTER

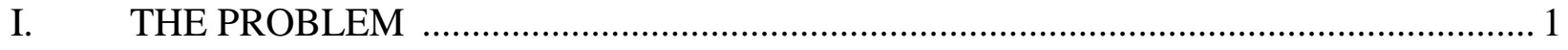

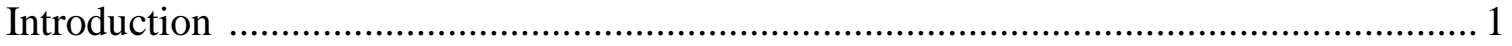

Purpose of the Study ......................................................................................... 4

Objectives of the Study ....................................................................................... 4

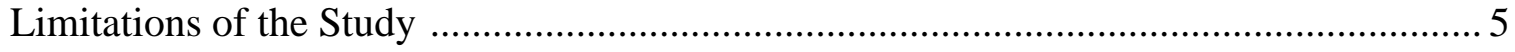

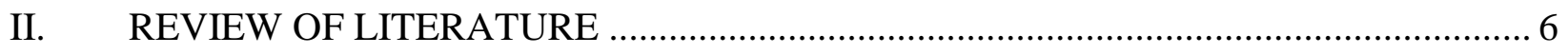

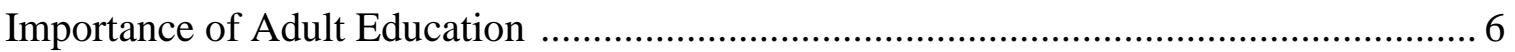

Importance of Adult Education in Agriculture ........................................................ 7

Developing Adult Education Philosophies in Agricultural Education ........................... 9

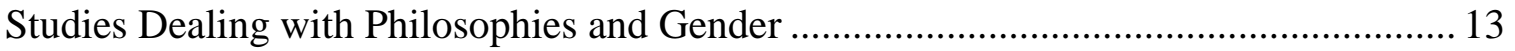

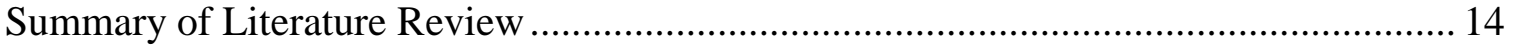

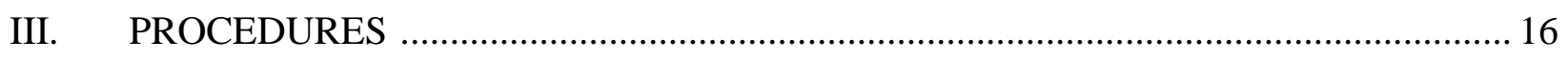

Specific Objectives .......................................................................................... 16

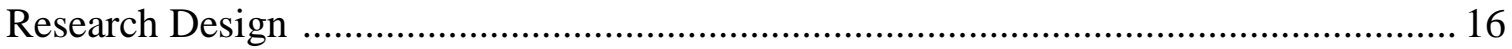

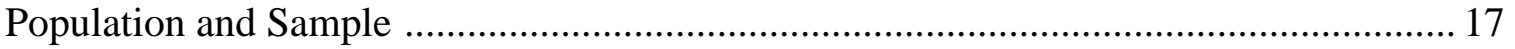

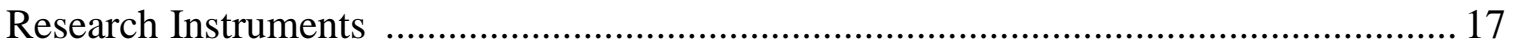

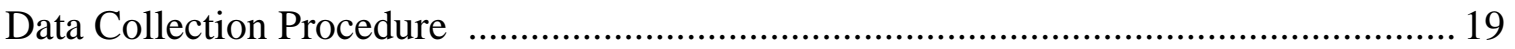

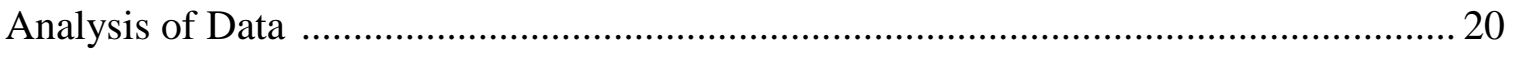

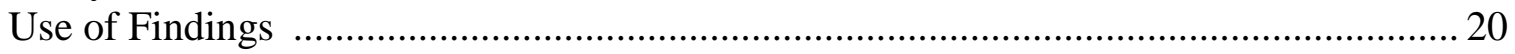

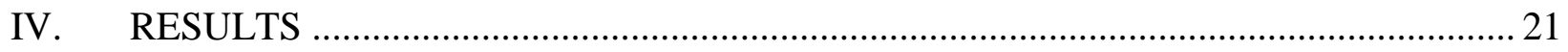

V. SUMMARY, CONCLUSIONS, AND RECOMMENDATIONS ................................ 32

Methodology

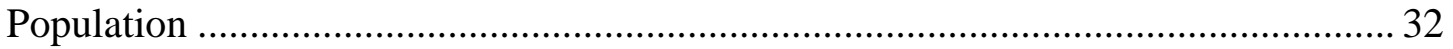

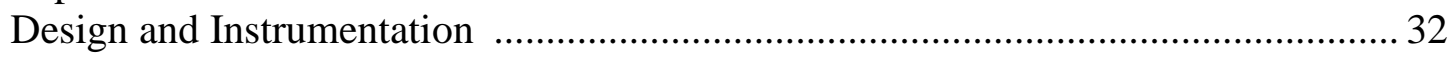

Validity and Reliability of the Instrument ........................................................ 33 


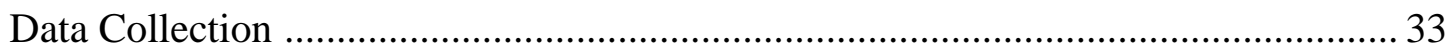

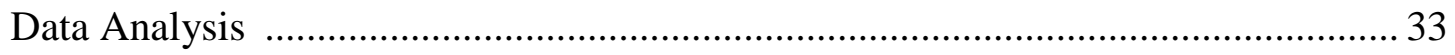

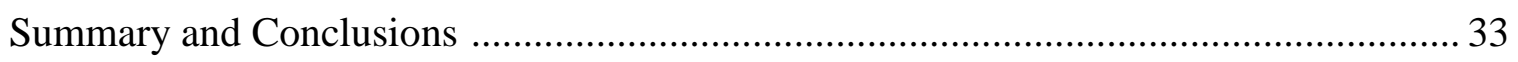

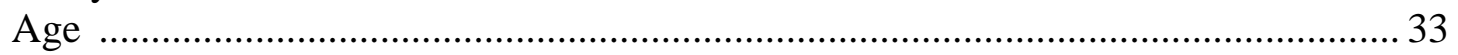

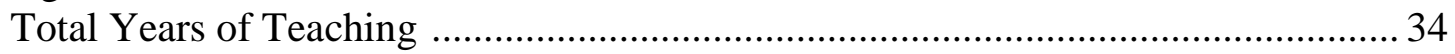

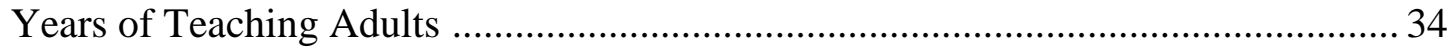

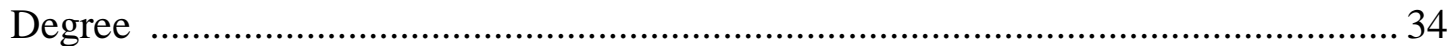

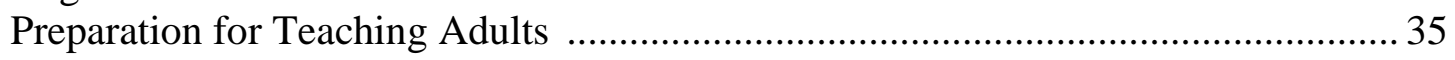

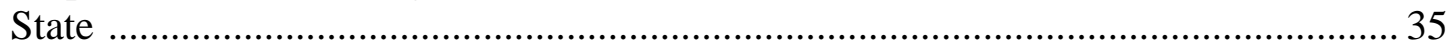

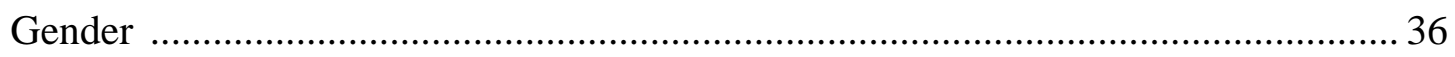

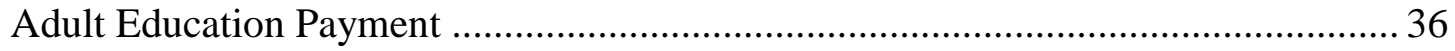

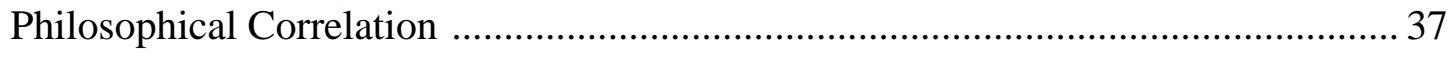

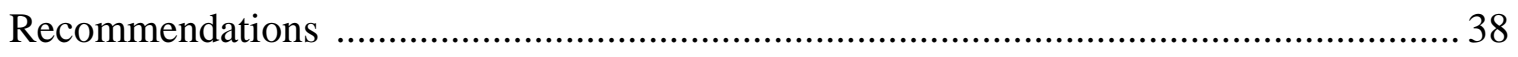

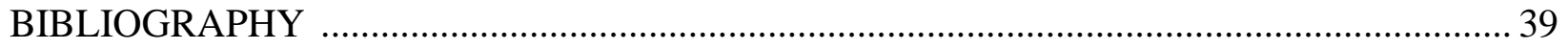

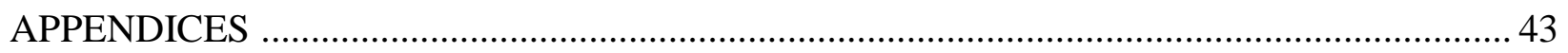

APPENDIX A: Cover Letter to Sample of Secondary Agricultural Teachers .......................... 44

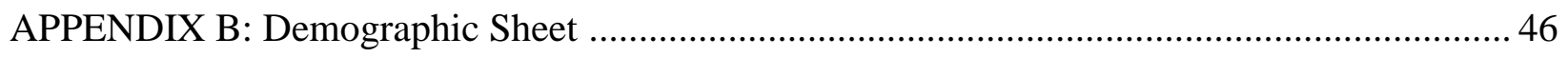

APPENDIX C: Philosophy of Adult Education Inventory (PAEI) ...................................... 48

APPENDIX D: Cover Letter for PAEI Score Sheet and Philosophy Information Sheet ............50

APPENDIX E: PAEI Score Sheet and Philosophy Information Sheet .................................. 52

APPENDIX F: Two-Week Follow-Up Letter to Non-Respondents ......................................55

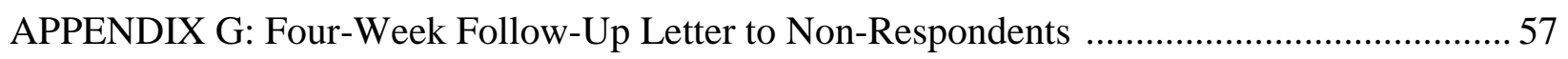

APPENDIX H: Cover Letter to Sample Non-Respondents for Double Dip Methodology ......... 59 


\section{LIST OF TABLES}

Table 1 Descriptive Statistics for Demographic Data .................................................. 23

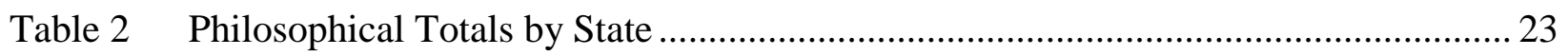

Table 3 Correlation between Philosophical Categories and Demographic Variables............. 25

Table 4 ANOVA for Educator Groups Variable ........................................................ 26

Table 5 ANOVA for State Variable ......................................................................... 27

Table 6 ANOVA for Gender Variable ...................................................................... 28

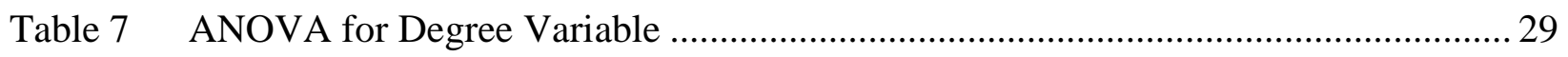

Table 8 ANOVA for Adult Education Preparation Variable ............................................ 30

Table 9 ANOVA for Adult Education Payment Variable............................................... 31 


\section{CHAPTER I}

\section{THE PROBLEM}

\section{$\underline{\text { Introduction }}$}

Educators have long debated over the best way to teach adults. Until 1920, the only recognized process of education was termed pedagogy. Pedagogy is the methodological process of teaching and refers to the education of minors or traditional students (Kussrow, 1997).

In 1927, Edward Lindeman introduced the concept of andragogy, which is the study of adult education. Knowles described andragogy as a "model of assumptions about learners"(as cited in Kussrow, 1997, p. 3) and as a technique of working with adults. However, most recently it is viewed as "a set of assumptions and methods pertaining to the process of helping adults learn" (Darkenwald and Merriam, 1982, p. 14).

Lindeman thought that a new teaching and learning paradigm was needed because andragogy differed greatly from pedagogy. Knowles (1970) considered andragogy the complete opposite of pedagogy and believed that pedagogy should only be concerned with the teaching of children. This view was based on the four premises of self-concept, the role of experience, readiness to learn, and orientation of learning (Brockett and Merriam, 1997). Apps (1981) believed that adults learn differently from youth and traditional students because of their life experiences, maturation, academic behavior, past problems, and current problems faced by many adults in today's society.

Because youth and adults differ in many ways, the methods used to teach them also must differ. Apps (1981) stated that adult educators should know their students, draw class content from students' experiences, tie theory to practice, provide a learning climate, offer many teaching formats through a variety of techniques, provide feedback, help students acquire 
resources, and be available to students out of class. Wilkinson (1984) suggested that good teachers supported the learners' choice to learn, stimulated curiosity in the learner, motivated students to learn, helped students construct a critical thinking approach, used many different teaching methods, and encouraged independent study out of the classroom.

If these traits describe what makes a good adult educator, then how are such traits obtained? Over the years, theorists have related educators' teaching styles to their philosophies. Educational philosophy is the view of how education should be conducted and the general guidelines for teaching (Beder, 1989). Researchers of andragogy have other reasons for believing that a personal philosophy of education is important.

Elias and Merriam (1980) believe that one's philosophy should be the guiding principle behind actual practice. Similarly, Apps (1985) believed that philosophy should guide practice and educators who review their philosophies frequently could improve their skills in adult education (Beder, 1989). Beder opposed App's view. He stated, “philosophy for the most part, has developed from purpose, because adult education has been more affected by the social function it serves than by the thought systems associated with it" (Merriam \& Cunningham, 1989, p. 38). Over time, philosophies of adult education have changed. Apps, Elias and Merriam, and Beder have different philosophical frameworks to describe adult education. For the purposes of this research study, Elias and Merriam's framework will be used. The six philosophies proposed by Elias and Merriam are categorized as liberalism, progressivism, humanism, behaviorism, radicalism, and philosophical analysis (Brockett, and Merriam, 1997). A brief description of each philosophy follows.

Liberal adult education emphasizes the transmission of a body of organized knowledge and the development of intellectual powers. 
Progressive adult education stresses learning as problem solving, the acquisition of practical skills, and the promotion of social change.

Behaviorist adult education focuses on behavioral modification, learning through reinforcement and instructional management by objectives.

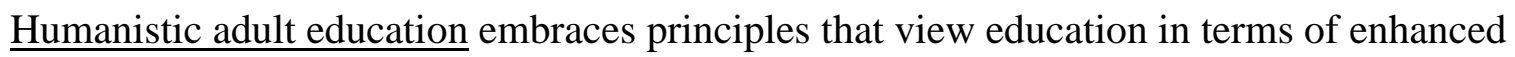
personal growth and development.

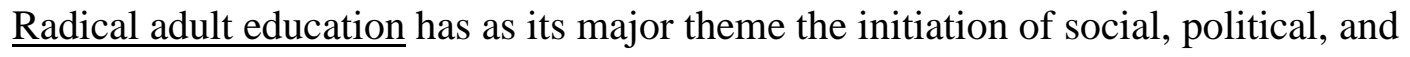
economic change.

Analytical adult education is concerned primarily with the need to clarify concepts and arguments used in theoretical discourse.

Adult education is essential in today's society. Without formal education after high school, our society would progressively become dependent upon government welfare systems. This is due in part to the division of labor and specialization in the workplace. What a person learns during youth needs to be updated and revised if the knowledge is to be relevant to the person as an adult (Beder, 1989).

Beder's premise is especially true with regard to the agricultural industry. Technologies used in production agriculture are in a state of rapid change. Without adult and technology courses in agriculture, it would be difficult for farmers and other agriculturists to learn how to use new technologies. One technology that agriculturists are using is computers. Microcomputers are valuable tools in the agricultural industry. Agriculturists use computers to keep livestock records, monitor market trends, and search for relevant agricultural information on the Internet. A study done by Bowen and Eseolme (1990) discovered that of the farmers who used computers $75 \%$ had some college education. Non-users had only a high school diploma or had not graduated from high school. 
A study by Ford (1995) showed that the average age of farmers was about 55 years and many of them did not have more than a high school education. Adult technology and agriculture programs are essential for these farmers if they are to acquire the necessary knowledge to remain competitive in the market place.

Are adult technology and agriculture classes helpful to farmers if the subject matter is presented in a manner consistent with the principles of adult education? Are adult learners more receptive to educational opportunities when the learning environment is structured specifically for an adult audience? Do Pennsylvania, West Virginia, and Virginia secondary school agriculture teachers, who have been trained under mostly pedagogical philosophies, demonstrate a different philosophical stance (i.e. andragogy-based) when teaching adults?

To determine the philosophy of adult educators, Zinn (1983) developed a survey called the Philosophy of Adult Education Inventory (PAEI). The PAEI allows the educator to determine his/her philosophy by rating him/herself on his/her views of the liberal, progressive, behaviorist, humanist, and radical philosophies. The PAEI produces a "likely" philosophy of adult education, if completed in an accurate manner (McKenzie, 1985).

\section{Purpose of the Study}

Limited research concerning the philosophies of adult education in agricultural education programs has been completed. No research was found that addressed this problem in the states of Pennsylvania, West Virginia, and Virginia. The purpose of this study was to increase understanding of adult education philosophies as practiced by Pennsylvania, West Virginia, and Virginia secondary school agriculture teachers. 


\section{Objectives of the Study}

The central problem of this study was to assess adult education philosophies practiced by Pennsylvania, West Virginia, and Virginia agricultural education teachers. Specific objectives were to:

1. Determine the demographics of Pennsylvania, West Virginia, and Virginia agriculture teachers who may have taught an adult technology class in agriculture during 1998-99.

2. Assess Pennsylvania, West Virginia, and Virginia agriculture teachers' philosophies of adult education using the Philosophy of Adult Education Inventory.

3. Determine if significant relationships exist between Pennsylvania, West Virginia, and Virginia agriculture teachers' philosophies and selected demographic variables.

4. Determine if significant differences exist in Pennsylvania, West Virginia, and Virginia agriculture teachers' philosophies when compared by years of experience, degree level, specialized course work, and remuneration.

\section{Limitations of the Study}

The study was limited to secondary school agriculture teachers $(\mathrm{N}=657)$ in Pennsylvania, West Virginia, and Virginia who may have taught adults in their local communities during the 1998-99 academic year. The PAEI may not accurately represent all adult education philosophies through its listing of questions and responses. 


\section{CHAPTER II}

\section{REVIEW OF LITERATURE}

The purpose of this study was to increase understanding of adult education philosophies as practiced by Pennsylvania, West Virginia, and Virginia secondary school agriculture teachers. To accomplish this purpose the following literature review addressed 1) the importance of adult education, 2) the importance of adult education in agriculture programs, and 3) developing adult education philosophies in agricultural education.

$\underline{\text { Importance of Adult Education }}$

Adult education is very important in the United States. Many adults depend on adult courses to make their lives better. Adult education is diverse. Specialized courses have been developed to address many aspects found in adult life. One such course is concerned with worker's education.

Workers' education refers to education for those who work. The employer often pays for these educational courses. In the past twenty years, workers' education has focused on training people to keep jobs, train for new jobs, and creating new businesses in which to work (Hellyer and Schulman, 1989).

Adult education in the workplace is common today. One reason for increased job training has been the increased use of new electronic technologies in the workplace. Since the personal computer was introduced in 1977, almost every company or business has adopted one or more into the workplace. With personal computers have come many software programs for different and specific purposes in the business, academic, and agricultural domains. Companies have had to incorporate adult education classes to train their employers to use this software.

Another reason for increased adult education courses has been the prominence of renewal in licenses and certificates, such as teaching certificates. Nine percent of the courses taken in the 
United States were for license or certificate renewal in 1984. The classes taken to renew licenses usually are required or mandated classes. Mandated classes are on the rise in the workplace. As such, it has become more challenging to make adult education classes, often resented by workers, into worthwhile learning experiences (Rachal, 1989).

Importance of Adult Education in Agriculture

In moving from general adult education to adult education in agriculture, mandated classes are not an issue. Young and adult farmers or people with agriculturally related jobs may not be forced to take continuing education classes (the exception would be vocational and agricultural education teachers) in order to maintain their employment.

Stensland (1955) stated that adult education starts with the wants and needs of adults. This is true especially in adult agricultural education programs. There are three institutions that cater to farmers and agriculturists. First, colleges and universities offer some courses designed for adult agriculturists. Often these classes are created for secondary school agriculture teachers or people interested in a career in the agriculture industry.

A second institution is the Cooperative Extension Service (CES). The CES is the world's largest publicly supported informal adult education provider. The purpose of CES is to disseminate research-based information from land grant colleges and universities to interested parties.

Lately, the teaching effectiveness of the Cooperative Extension Service has come into question. A study by Seevers (1995) found that "most extension professionals are not trained to assume the role as an adult educator" (p. 1). Also, the study showed that most of the Ohio CES employees had degrees in technical subjects and had no formal adult education background (Seevers, 1995). 
Local secondary schools also provide specialized classes in agriculture. These classes are for the young and adult farmers of the area. Usually a young farmer is a person who has graduated high school and is no more than 35 years of age. Whereas, an adult farmer is any farmer or agriculturalist over the age of 35. The Young Farmers Association is instrumental in providing services to young agriculturalists. It provides the opportunity for these farmers to engage in leadership activities, community improvement, and social and recreational activities (Bender et. al., 1972).

The Smith-Hughes Act of 1917 was responsible for establishing a program that receives Federal and State money for promoting vocational agriculture classes in high schools. These classes are not adequate to supply information to people who are preparing to start a farm, are already engaged in farming, or another agriculturally related field. Therefore, young and adult farmer classes should be provided (United States Department of Health, Education, and Welfare, 1978). A complete vocational agriculture program includes training in agricultural careers for secondary school students, out-of-school young farmers, and adult farmers (Bender et. al., 1972). Adult education classes, as part of the secondary school system, may be dependent upon local school administrators' viewpoints. Both, Viterna (1973) and Miller and Krill (1985) (as cited in Adelaine \& Foster, 1989) found that school administrators in Nebraska and Ohio, respectively, viewed young farmer classes favorably as part of secondary vocational agriculture programs. Miller (1983) (as cited in Chizari \& Taylor, 1991) commented that support not only from the local school, but also from business and industry, agriculture colleges, and government agriculture agencies was necessary if adult agriculture programs are to be successful.

Adult agriculture programs are more important today than ever before because of rapid advances in technology, innovative marketing, new farm management techniques, new agricultural laws, and regulations (Chizari \& Taylor, 1991). A study by Lilley, et al. (1987) (as 
cited in Chizari \& Taylor, 1991) suggested that adults in production agriculture needed classes on feeds, crop production, soil sciences, farm records and management, farm mechanics, long range planning, government laws, and regulations. Drueckhammer and White (1984) (as cited in Birkenholz \& Maricle, 1991) suggested that because of the declining numbers in agricultural producers, the need for production information has decreased also. Harbstreit (1987) (as cited in Birkenholz \& Maricle, 1991) stated that adult agricultural education programs used to focus on improving the efficiency in production agriculture and managerial skills, now the focus has shifted to problems of agricultural consumers, homeowners, gardeners, and concerned citizens. Nur, Birkenholz, and Stewart (1989) (as cited in Birkenholz \& Maricle, 1991) agreed that a shift in the target audience and the knowledge base for adult education programs has occurred. The shift in adult agriculture education programs should have caused a shift in the teaching methodologies of adult educators. An important factor in an adult educators' purposes, methodology, and teaching processes is their philosophy of education (Wingenbach, 1996). Developing Adult Education Philosophies in Agricultural Education

Philosophies of adult education are the beliefs about the way in which adult education should be conducted and the general principles that guide practice (Beder, 1989). Therefore, developing a working philosophy of adult education is important to adult educators when planning programs. Adult educators have derived several reasons why developing a working philosophy can benefit an educator. Zinn (1990) listed these reasons and their originators as follows.

- Provide a systematic plan for making judgments and decisions (Stewart, 1973).

- Help separate trivial and worthwhile information (Maxcy, 1980).

- Develop critical thinking skills (Phoenix, 1958).

- Better personal meaning in the educator's life (Apps, 1973). 
- Notice conflicts in philosophy and between beliefs and actions and resolve them (Phoenix, 1958).

- Provide insight into the teacher-learner, learner-subject matter, and subject matter-world relationship (Maxcy, 1980).

- Clarify how work relates to individual and society problems (Apps, 1973).

- Help the educator ask and answer better questions about educational programming (Apps, 1973).

- Help the individual understand himself in relation to career, resolve conflict, to be selfdirected, and to be a leader (Apps, 1973).

Many leaders in adult education have developed principles to help educators form a working philosophy. Apps suggested the following guidelines, consisting of four phases, to develop one's own adult education philosophy.

- Identify beliefs about adult education by asking oneself questions about the learner, the overall purpose of adult education, content or subject matter, and the learning process.

- Search for contradictions in the beliefs.

- Discover where the basis for these beliefs came from and find supporting beliefs.

- Make judgements about the beliefs held.

Many educators find Apps' method too complex to use in developing their philosophies. It involves a complete compilation of new and changing educator's beliefs along with a comprehensive analyzed philosophy (Zinn, 1990).

Another leader in adult education, Beder (1989), formed principles that are not as lengthy and could be used to build a foundation of philosophy in adult education. The five principles as follows were found in a study by Wingenbach (1996, p. 68): 
1. Whether society is basically good or is inherently flawed, it can and should be improved. In this, adult education can and should play a major role.

2. If individuals and ultimately societies are to prosper, learning must continue throughout life.

3. Adults are capable of learning and should be treated with dignity and respect.

4. All adults should have access to learning the things required for basic functioning in society.

5. Although adults may or may not differ from pre-adults regarding the basic cognitive processes of learning, the context of adult education differs substantially from the context of pre-adulthood. Hence, adults should be educated differentially from pre-adults. Zinn (1983) designed the Philosophy of Adult Education Inventory (PAEI), based on five philosophical tenets, as practiced by adult educators. The philosophical tenets listed briefly in the introduction were derived from the works of Elias and Merriam (1980). A more in-depth description of these philosophical ideologies is addressed herein.

Liberal: This adult philosophy purpose is to develop intellectual powers. Liberals always seek knowledge. They work to transmit knowledge and clearly direct learning. The educator is the "expert". He/she directs the learning process with complete authority. Learning methods used include lecture, study groups, and discussion. Socrates, Plato, and Piaget were practitioners of the liberal philosophy. (Note: Liberal adult education does not refer to liberal political views, it is related to Liberal Arts.)

Behaviorist: The purpose of the Behaviorist adult philosophy is to promote behavioral change to guarantee that societies standards and expectations are upheld. Environmental influence is strong in this philosophy. The traits of the behaviorist teacher are close to those of the liberal. The behaviorist "manages" the learning process and directs learning. Behaviorist 
concepts include mastery learning and standards-based. Some methods of teaching that behaviorist educators use include programmed instruction, contract learning, and computer guided instruction. Vocational training and teacher certifications are both behaviorist practices. Skinner, Thorndike, and Steinberg all believe in the behaviorist philosophical tenet.

Progressive: This philosophy of adult education is concerned with the well-being of society and an individual's role in society. Learners of this philosophy need problem solving skills and practical knowledge. Teaching methods used in this philosophy include problem solving, scientific method, and cooperative learning. The educator is an organizer who guides learning instead of directing learning and also evaluates the learning process. Progressive proponents include Spencer, Dewey, and Lindeman.

Humanistic: The humanistic philosophy seeks to facilitate personal growth and development. Humanists are highly motivated and self-directed learning; responsibility to learn is assumed by the learner. The humanist educator facilitates learning but does not direct learning. The educator and learner are "partners." Concepts that define the humanistic philosophy include experiential learning, individuality, self-directed, and self-actualization. Humanistic teaching methods contain group discussion, team teaching, individualized learning, and the discovery method. Rogers, Maslow, Knowles, and McKenzie are facilitators of the humanistic philosophy.

\section{Radical: The Radical adult education philosophy or Reconstructionist philosophy} promotes social, political, and economic change through education. The educator and learner are equal partners in the learning process. The educator is the coordinator of the class and makes suggestions but does not direct the learning process. This philosophy embraces concepts such as noncompulsory learning and deschooling. Exposure to the media and people in real life situations are considered effective teaching methods. Holt, Freire, and Illich are proponents of the Radical adult education philosophy. 


\section{$\underline{\text { Studies dealing with Philosophies and Gender }}$}

In a study by Wingenbach (1996), gender was shown to have significant differences in the Behaviorist and Radical orientations. The population of this study was students enrolled in the researcher's classes at West Virginia University. All females were found to have higher mean scores than males in the Radical philosophical orientation. As noted by Zinn (1990), "Radical [Reconstructionist] adult education also runs against the current of American value patterns" (p. 56). Wingenbach (1996) wrote that female students' may have strong beliefs for the Radical philosophical orientation "due to its focus in social change, empowerment, and equality" (p. 72).

In the Behaviorist orientation, female graduates had higher mean scores than did male graduates, except in the undergraduate group. In this group the males had higher mean scores. The students did not differ statistically in their mean scores for the Behaviorist, Humanistic, or Radical orientations. These findings differ from the findings of McKenzie (1985). In his study, McKenzie (1985) found significant differences in all five philosophical orientations while comparing business trainers, religious educators, and adult education graduate students (p. 20).

Due to the significant differences in Liberal and Progressive orientations between these groups of students certain assumptions about these orientations were apparent in both groups' thinking, while completing the PAEI inventory. Some assumptions might be: (a) the group of graduate students scored higher in the Progressive orientation because of their teaching experience (about 12 years), which has given them an advantage in teaching practical skills like problem solving; and (b) the group of undergraduates scored higher in the Liberal orientation because of their lack of experience, which has not allowed them an opportunity to apply theoretical knowledge outside the university.

Despite the differences in age and years of experience between the two groups in this study, these students can identify, clarify, and reflect upon their educational beliefs and values. 
The significant differences between the groups in the Liberal orientation may represent the findings of Berger and Luckmann (1966). That is, when individuals enter an existing institution, they begin to express the views reflected in that institution; they begin to speak a common language. In time, once the undergraduate students have gained experience, they may want to repeat the PAEI to check for shifts in their philosophical orientations.

The relationship between identifying a specific adult education philosophy and agricultural education should be an important educational factor for secondary school agricultural educators. Youth and adults differ greatly in their preferred learning styles and educational environments. If agriculture teachers can accept these basic differences, then the teaching methods, procedures, activities, learning environments, and evaluations must differ also for adult audiences. There remains the question of whether actual differences do exist when secondary agriculture teachers teach adults? Previous research shows that significant differences do exist between educators when compared by years of experience and/or gender (Wingenbach, 1996; Zinn, 1990) and educational level (McKenzie, 1985). The researcher is left to ponder, does a methodological difference in agricultural programming exist for adult and pre-adult participants in Pennsylvania, West Virginia, and Virginia? Do agriculture teachers from Pennsylvania practice a significantly different adult educational philosophy than teachers from Virginia or West Virginia?

\section{$\underline{\text { Summary of Literature Review }}$}

Adult education has become important in the United States for those people who wish to learn a new trade, want to learn more about topics that interest them, or for those who are required to attend classes for their occupation. Research has shown that adults do not learn by the same methods as pre-adults. Therefore, the increase in adult education classes makes it necessary 
for educators to learn not only new methods and techniques but also to form new philosophies when teaching adults.

A working philosophy of adult education is needed before the teaching of adults can begin (Wingenbach, 1996). Apps, Beder, and Zinn have all designed techniques that allow adult educators to develop personal philosophies of adult education. The review of literature revealed that no studies have been conducted to assess agriculture teachers preferred philosophies of adult education in Pennsylvania, West Virginia, and Virginia. 


\section{CHAPTER III}

\section{PROCEDURES}

The purpose of this study was to increase understanding of adult education philosophies as practiced by secondary school agriculture teachers in Pennsylvania, West Virginia, and Virginia.

\section{Specific Objectives}

1. Determine the demographics of Pennsylvania, West Virginia, and Virginia agriculture teachers who may have taught an adult technology class in agriculture during 1998-99.

2. Assess Pennsylvania, West Virginia, and Virginia agriculture teachers' philosophies of adult education using the Philosophy of Adult Education Inventory (PAEI).

3. Determine if significant relationships exist between Pennsylvania, West Virginia and Virginia agriculture teachers' philosophies and selected demographic variables.

4. Determine if significant differences exist in Pennsylvania, West Virginia, and Virginia agriculture teachers' philosophies when compared by years of experience, specialized coursework, level of degree, and remuneration.

\section{$\underline{\text { Research Design }}$}

Descriptive survey methodology and a correlational design were used in this study. The primary advantage in using this research methodology was the accumulation of large amounts of data in a limited time frame. The correlational design allows for discovery, clarification and/or explanation of relationships between and among the research variables (Borg \& Gall, 1989).

The dependent variable was PAEI scale scores. The independent variables were educational degree attained, years of teaching experience, geographic location, age, and gender. Both the dependent and independent variables were ascertained after their natural occurrence. 


\section{$\underline{\text { Population and Sample }}$}

The target population of this study included all agricultural education teachers from Pennsylvania ( $\mathrm{N}=259)$, West Virginia $(\mathrm{N}=95)$, and Virginia $(\mathrm{N}=303)$ who taught classes during the 1998-99 academic year and who were listed in their respective state's Agricultural Educators Directory for the 1998-99 academic year. The researcher obtained original copies (paper and electronic) of these directories from the State Supervisor for Agricultural Education. From these rosters, the population of agriculture teachers was determined to be 657 . Proportional stratified sampling was employed to ensure equal representation from each state identified in the target population. The characteristics of the entire population were the main concern in this study, therefore each stratum was represented in the sample in exact proportion to its frequency in the total population (Ary, Jacobs, \& Razavieh, 1996). A sample size of 314 was needed to represent this population (Krejcie \& Morgan, 1970).

\section{$\underline{\text { Research Instruments }}$}

The tool used to obtain information was the Philosophy of Adult Education Inventory (PAEI). The PAEI was developed by Lorraine M. Zinn to help the adult educator to determine his or her philosophy of education and compare it to other educators' philosophies. The PAEI has been used in many Masters theses (such as this one) and Doctoral dissertations, and has been cited in many professional publications (Zinn, 1994).

The PAEI is partially based on the Training Style Inventory (Brostrom, 1986). This tool was used to assist people who worked in a training capacity to determine their teaching styles. The responses on the inventory determine the teaching profile of the trainer. The four training orientations were Humanist, Behaviorist, Functionalist, and Structuralist (Zinn, 1994). 
The PAEI contains five orientations. Humanistic and Behaviorist are on both inventories. Structuralist is close to the Liberal Philosophy and Functionalist is close to the Progressive orientation. The Radical Philosophy was not covered in the Training Style Inventory.

The PAEI contains 75 Likert-type statements on a seven-point scale, with 1 = strongly disagree, $4=$ neutral, and $7=$ strongly agree. Total scores ranged from 15 to 105 for each of the philosophical orientations. These scores signify the individuals' views toward the five philosophies of adult education.

The educators' highest score is the score that most closely describes their philosophy. The lowest score is the philosophy least like the educators' philosophy. A score of 95 to 105 indicates that the educator strongly agrees with a philosophy. A score of 15-25 indicates that the educator strongly disagrees with a philosophy. Most educators have one philosophy that receives a high score. Therefore, that is the philosophy that the educator agrees with and uses when teaching. However, it is not uncommon for an educator to have two philosophies that have high scores. This is common because some of the philosophies overlap. Educators who have other combinations of high scores or have three or more close scores should review their beliefs and look for contradictions (Zinn, 1983). Some common philosophy combinations are Liberal and Behaviorist, Progressive and Humanistic, Progressive and Radical, and Humanistic and Radical (Zinn, 1983).

In previously published studies by Zinn (1987) and Wingenbach (1996), the PAEI had been determined to be a reliable and valid instrument for measuring adult education philosophies with reported Cronbach's alpha levels at 0.75 and 0.86 respectively. The PAEI was designed to be administered, scored, and interpreted by the respondent (Zinn, 1983). The instructions sent with Zinn's inventory were the original instructions she sends with the PAEI. An additional 
instrument was sent to assess respondents' educational degree attained, years of teaching experience, geographic location, age and gender.

\section{$\underline{\text { Data Collection Procedure }}$}

Data collection began on May 7, 1999. For the study, the PAEI instrument, demographic questionnaire, cover letter, and return envelopes were mailed to the sample group in Pennsylvania, West Virginia, and Virginia. The PAEI was used to gather data about the teachers' philosophical views toward adult education. Mailed questionnaires allow a large number of people over an extended area to be interviewed. The mailed questionnaire is also popular because it allows the respondents to be anonymous and produces responses that are more truthful than if interviewed by a person (Ary, Jacobs, \& Razavieh, 1996).

Problems with mailed questionnaires result from misinterpretation of the questions by the respondents. Also, many questionnaires are not returned. However, employing appropriate follow-up procedures can increase the number of returned questionnaires (Ary, Jacobs, \& Razavieh, 1996).

Data from this study were obtained through the use of the PAEI and the demographic questionnaire. Both were mailed to the agricultural education teachers in Pennsylvania, West Virginia, and Virginia. Each survey contained a cover page and a self-addressed, stamped envelope. The cover letter explained the purpose of the study and contained the researcher's signature. The self-addressed, stamped envelope was enclosed to encourage the return of the questionnaire.

Two weeks after the initial mailing, follow-up postcards were sent out to all nonrespondents. This card reminded the respondent that they had received the PAEI and a questionnaire and that their response is important to the study. The respondents were also urged to contact the researcher if they never received the PAEI and questionnaire or had misplaced it so 
that another one could be sent as suggested by Ary, Jacobs, \& Razavieh (1996). Four weeks after the first mailing, a second postcard reminder was sent to all nonrespondents.

Nonresponses are important in survey research. The nonrespondents cannot be dismissed as unimportant because using only information from the self-selected groups of respondents can cause error in the study. These subjects do not necessarily represent the population (Ary, Jacobs, \& Razavieh, 1996). Nonresponses in this study were dealt with using the double-dipped sampling methodology. This allows the researcher to compare the respondents and nonrespondents. For the purposes of this study, five weeks after the initial mailing, the researcher sent $10 \%$ of the nonrespondents a new PAEI, cover letter, and demographic sheet. The mean responses of these subjects were statistically compared to the respondents to determine if significant differences existed (Ary, Jacobs, \& Razavieh, 1996). Data collection ended July 23, 1999.

\section{Analysis of Data}

Data collected were analyzed using the Statistical Package for Social Sciences for Windows (SPSS). Descriptive statistics such as frequencies, means, and standard deviations, as well as correlational and multivariate analyses were used to describe and analyze the research results.

\section{$\underline{\text { Use of Findings }}$}

The findings from this study may be used as a means to improve adult education in Pennsylvania, West Virginia, and Virginia. By allowing adult educators to discover their philosophies of adult education they can improve their teaching styles to more effectively teach the adults in their classes. 


\section{CHAPTER IV}

\section{RESULTS}

The purpose of this study was to increase understanding of adult education philosophies as practiced by secondary school agriculture teachers in Pennsylvania, West Virginia, and Virginia.

There were two groups in this study. One group was composed of secondary agriculture teachers in Pennsylvania, West Virginia, and Virginia that taught adult education classes as part

of their agriculture program. The other group was composed of secondary agriculture teachers in the same three states who did not teach adult education classes.

The sample size for the study was 314 teachers comprised of 93 adult educators and 221 non-adult educators. A total of 118 surveys returned were usable in this study. The return rate for this study was 38\%. However, looking at the return rate of each group, 75 of the 93 adult educators returned their survey. This is a return rate of $81 \%$. Of the non-adult educators only 43 of the 221 educators returned their surveys causing the return rate to be only $19 \%$.

To determine if there was a significant difference between the respondents and nonrespondents an Analysis of Variance (ANOVA) was ran between the two groups. Nonrespondents were surveyed using the double-dipped sampling. No significant differences were found between the two groups when dealing with philosophies.

Each respondent was supplied a demographic sheet along with the PAEI. The sheet asked questions including state, age, gender, degree, years of teaching secondary school, number of years teaching adults, whether the educator received formal education for teaching adults, and whether the educator received monetary compensation. Table 1 shows the descriptive statistics for each of the demographic variables. 
Of the 118 respondents, 75 were not adult educators. Respondents were from Pennsylvania (49), followed by Virginia (45), and West Virginia (24). The survey respondents were primarily male (99). Slightly more than half of the respondents has a Masters degree or Ph.D. Three quarters of those responding teach adults and over half responded that they have received some formal training in teaching adults. Almost $60 \%$ of the survey respondents are paid to teach adults.

The number of educators in each state that agree with one of the five philosophical tenants is indicated in Table 2. Most educators in the tri-state area identified with the Progressive philosophy. None identified with the Liberal philosophy.

The total number of Progressive educators was 80, Behaviorist 25, Humanist 9, and Radical 4. Pennsylvania educators had the highest Progressive group at $71.4 \%$, Virginia at $68.9 \%$, and West Virginia at 58.3\%. West Virginia has the highest Behaviorist rate at 29.2\%, Pennsylvania at $20.4 \%$, and Virginia at $17.8 \%$. West Virginia had the highest rate of Humanist philosophies followed by Virginia and Pennsylvania, respectively. Those rates were 12.5\%, $8.9 \%$, and $4.1 \%$, respectively. Pennsylvania and Virginia each had two Radical respondents. 
Table 1

Descriptive Statistics for Demographic Data

\begin{tabular}{ccc}
\hline \hline Variable & Frequency & Percent \\
\hline Group (n=118) & 75 & 63.6 \\
Non AE Sample & 43 & 36.4 \\
AE Sample & & \\
State (n=118)* & 49 & 41.5 \\
Pennsylvania & 45 & 38.1 \\
Virginia & 24 & 20.3 \\
West Virginia & & \\
Male & 99 & 83.9 \\
Female & 19 & 16.1 \\
Gender (n=118) & & 50.8 \\
Masters & 60 & 44.1 \\
Bachelors & 52 & 0.8 \\
PhD & 1 & 74.6 \\
Degree (n=113)* & & 22.0 \\
Yes & 88 & \\
No & 26 & 52.5 \\
Teach Adults $(\mathrm{n}=114)^{*}$ & & 40.7 \\
Yes & 62 & 58.5 \\
No & 48 & 32.2 \\
YE Preparation(n=110)* & 69 & \\
No & 38 & \\
AE Payment(n=107) & & \\
\hline \hline
\end{tabular}

*Due to rounding not all demographic percentages equal $100 \%$.

Table 2

Philosophical Totals by State

\begin{tabular}{|c|c|c|c|c|c|c|c|c|c|c|c|c|}
\hline \multicolumn{13}{|c|}{ Philosophical Categories } \\
\hline \multirow[b]{2}{*}{ State } & \multicolumn{2}{|c|}{ Liberal } & \multicolumn{2}{|c|}{ Behaviorist } & \multicolumn{2}{|c|}{ Progressive } & \multicolumn{2}{|c|}{ Humanist } & \multicolumn{2}{|c|}{ Radical } & \multirow[b]{2}{*}{ Total } & \multirow[b]{2}{*}{ Percent } \\
\hline & $\mathrm{n}$ & $\%$ & $\mathrm{n}$ & $\%$ & $\mathrm{n}$ & $\%$ & $\mathrm{n}$ & $\%$ & $\mathrm{n}$ & $\%$ & & \\
\hline PA & 0 & 0.0 & 10 & 20.4 & 35 & 71.4 & 2 & 4.1 & 2 & 4.1 & 49 & 100 \\
\hline WV & 0 & 0.0 & 8 & 17.8 & 31 & 68.9 & 4 & 8.9 & 2 & 4.4 & 45 & 100 \\
\hline VA & 0 & 0.0 & 7 & 29.2 & 14 & 58.3 & 3 & 12.5 & 0 & 0.0 & 24 & 100 \\
\hline Total & 0 & 0.0 & 25 & 21.2 & 80 & 67.8 & 9 & 7.6 & 4 & 3.4 & 118 & 100 \\
\hline
\end{tabular}

Table 3 shows the correlational relationship between the five philosophical categories and the selected demographic variables. The table shows correlation between continuous 
variables (in all capital letters) and rank and order variables (in lower case letters). Continuous variables are those that increase over time such as age. Rank and order variables are those that do not change over time like gender. Continuous variables are correlated using Pearson's Correlation while rank and order variables are correlated using Spearman's Rho.

The Davis Convention measures the association between variables. Davis (1971) provided a chart to show how a coefficient relates to the association of a variable.

\begin{tabular}{cc}
\multicolumn{2}{c}{ Conventions Used to Describe Measures of Association } \\
\hline Coefficient & Description of Association \\
\hline .70 to 1.00 & Very Strong \\
.50 to .69 & Substantial \\
.30 to .49 & Moderate \\
.10 to .29 & Low \\
.01 to .09 & Negligible \\
\hline
\end{tabular}

Davis Convention is helpful when looking at the relationships between variables and the philosophical categories. It allows the researcher to determine the association of the relationship between the philosophies and variables.

Data in table 3 indicates that there is a strong association between the Liberal and Behaviorist philosophies. There also is a strong association between the Behaviorist and Progressive philosophies. There is a substantial association between the Liberal and Progressive philosophies as well as the Humanistic and Progressive philosophies.

The Liberal philosophy has a statistically significant correlation with the Behaviorist, Progressive, Humanistic, and Radical philosophies. The Behaviorist philosophy correlates significantly with the Progressive, Humanistic, and Radical philosophies. The Progressive philosophy significantly correlates with the Humanistic and Radical Philosophies, and the humanistic philosophy significantly correlates with the Radical philosophy. 
Table 3 also shows the correlation between the philosophies and the demographic variables. There is a statistical difference at the .01 level between the State variable and the Humanistic philosophy, as well as, a statistical significant difference at the .05 level for the Payment variable and the Progressive philosophy. Both of these correlations show low associations according to the Davis convention but still are significant correlations.

Table 3

Correlation between Philosophical Categories and Demographic Variables

\begin{tabular}{|c|c|c|c|c|c|}
\hline & LIBERAL & BEHAVIOR & PROGRESS & HUMAN & RADICAL \\
\hline LIBERAL & & $.81 * *$ & $.59 * *$ & $.38 * *$ & $.29 * *$ \\
\hline BEHAVIOR & & & $.72 * *$ & $.42 * *$ & $.30 * *$ \\
\hline PROGRESS & & & & $.55 * *$ & $.26 * *$ \\
\hline HUMAN & & & & & $.48 * *$ \\
\hline \multicolumn{6}{|l|}{ RADICAL } \\
\hline $\mathrm{AGE}$ & .11 & .05 & .01 & .00 & .11 \\
\hline YRS & .17 & .17 & .06 & -.03 & .04 \\
\hline ADULTYRS & .15 & .09 & -.04 & -.01 & .13 \\
\hline State & .00 & -.02 & .09 & $-.27 * *$ & -.08 \\
\hline Gender & .06 & -.05 & .13 & -.02 & .10 \\
\hline Degree & .07 & .10 & .10 & .01 & .07 \\
\hline AE Preparation & .07 & .14 & .05 & .17 & .13 \\
\hline AE Payment & .10 & .09 & $.19 *$ & .07 & -.04 \\
\hline
\end{tabular}


Table 4 shows the Analysis of Variance between the five philosophical groups and the educators, adult or non-adult. There were no significant differences found to exist between the philosophies and the two groups of educators.

Table 4

ANOVA for Educator Groups Variable

\begin{tabular}{cccc}
\hline \hline Philosophy & Educator & Mean & F \\
\hline Liberal & Adult & 69.07 & .07 \\
& Non-adult & 68.57 & \\
& Total & 68.75 & \\
& Adult & 79.70 & \\
\hline Behaviorist & Non-adult & 81.29 & .14 \\
& Total & 80.71 & \\
& Adult & 84.30 & .05 \\
Progressive & Non-adult & 85.16 & \\
& Total & 84.85 & .05 \\
& Adult & 74.72 & \\
\hline Humanistic & Non-adult & 74.28 & \\
& Total & 74.44 & \\
& Adult & 68.95 & \\
\hline Radical & Non-adult & 68.48 & \\
& Total & 68.65 & \\
\hline \hline
\end{tabular}


Table 5 reports the Analysis of Variance between the State variable and the five philosophical tenants. The only statistically significant variance was between the Humanistic Philosophy and the state of Pennsylvania when compared to West Virginia. No other significant differences among mean ratings were found. The other states were closely related to the philosophies.

Table 5

ANOVA for State Variable

\begin{tabular}{cccc}
\hline \hline Philosophy & State & Mean & F \\
\hline Liberal & WV & 69.04 & .04 \\
& VA & 68.93 & \\
& PA & 68.45 & .11 \\
& Total & 68.75 & \\
\hline Behaviorist & WV & 81.50 & .34 \\
& VA & 80.80 & \\
& PA & 80.24 & \\
\hline Progressive & Total & 80.71 & $3.08^{*}$ \\
& WV & 85.58 & \\
& VA & 83.71 & \\
& PA & 85.53 & \\
\hline Humanistic & Total & 84.85 & .65 \\
& WV & 77.75 & \\
& VA & 75.31 & \\
\hline Radical & PA & 72.02 & \\
& Total & 74.44 & 70.33 \\
& WV & 69.22 & \\
& VA & 67.31 & 68.65 \\
\hline \hline
\end{tabular}

*Correlation is significant at the .05 level 
Table 6 shows the Analysis of Variance between the variable of gender and the five philosophical tenants. No statistical significance was found between gender and the five philosophical tenants that were compared in this study.

Table 6

ANOVA for Gender Variable

\begin{tabular}{cccc}
\hline \hline Philosophy & Gender & Mean & F \\
\hline Liberal & Female & 67.10 & .66 \\
& Male & 69.07 & \\
& Total & 68.75 & .05 \\
& Female & 80.21 & \\
\hline Behaviorist & Male & 80.81 & 2.33 \\
& Total & 80.71 & \\
\hline Progressive & Female & 81.11 & .00 \\
& Male & 85.57 & \\
& Total & 84.85 & 1.43 \\
\hline Humanistic & Female & 74.42 & \\
& Male & 74.44 & \\
& Total & 74.44 & 65.79 \\
\hline Radical & Female & 69.20 & 68.65 \\
\hline
\end{tabular}


Table 7 shows the Analysis of Variance between the variable of academic degree and the five philosophical tenants. The study found no statistically significant variance between the variable of degree and the five philosophies.

Table 7

ANOVA for Degree Variable

\begin{tabular}{|c|c|c|c|}
\hline Philosophy & Degree & Mean & $\mathrm{F}$ \\
\hline \multirow[t]{4}{*}{ Liberal } & $\mathrm{BS}$ & 68.19 & 1.63 \\
\hline & MS & 68.55 & \\
\hline & Ph.D. & 86.00 & \\
\hline & Total & 68.54 & \\
\hline \multirow[t]{4}{*}{ Behaviorist } & $\mathrm{BS}$ & 79.60 & .74 \\
\hline & MS & 81.05 & \\
\hline & Ph.D. & 91.00 & \\
\hline & Total & 80.47 & \\
\hline \multirow[t]{4}{*}{ Progressive } & $\mathrm{BS}$ & 84.27 & 1.52 \\
\hline & MS & 85.42 & \\
\hline & Ph.D. & 65.00 & \\
\hline & Total & 84.71 & \\
\hline \multirow[t]{4}{*}{ Humanistic } & $\mathrm{BS}$ & 73.87 & .90 \\
\hline & MS & 74.85 & \\
\hline & Ph.D. & 62.00 & \\
\hline & Total & 74.28 & \\
\hline \multirow[t]{4}{*}{ Radical } & $\mathrm{BS}$ & 67.52 & .99 \\
\hline & MS & 69.47 & \\
\hline & Ph.D. & 56.00 & \\
\hline & Total & 68.45 & \\
\hline
\end{tabular}


Table 8 shows the Analysis of Variance between the preparation variable and the five philosophical tenants. The study showed that there was no statistically significant difference between the adult education preparation and the philosophical tenant that an educator most closely relates.

Table 8 ANOVA for Adult Education Preparation Variable

\begin{tabular}{cccc}
\hline \hline Philosophy & AE Preparation & Mean & F \\
\hline Liberal & No & 68.56 & .01 \\
& Yes & 68.71 & \\
& Total & 68.65 & .44 \\
& No & 79.79 & \\
\hline Behaviorist & Yes & 81.15 & .27 \\
& Total & 80.55 & \\
\hline Progressive & No & 85.56 & 1.32 \\
& Yes & 84.35 & \\
& Total & 84.88 & 2.07 \\
\hline Humanistic & No & 73.21 & \\
& Yes & 75.42 & \\
& Total & 74.45 & \\
\hline Radical & No & 66.75 & 69.94 \\
& Yes & 68.55 & \\
\hline \hline
\end{tabular}


Table 9 shows the Analysis of Variance between payment variable and the five philosophical tenants. The study showed that there was no statistically significant variance between educators that are paid to teach adults and those educators who are not paid to teach adult classes.

Table 9

ANOVA for Adult Education Payment Variable

\begin{tabular}{cccc}
\hline \hline Philosophy & AE Payment & Mean & F \\
\hline Liberal & No & 67.89 & .53 \\
& Yes & 69.19 & \\
& Total & 68.73 & .43 \\
& No & 79.34 & \\
\hline Behaviorist & Yes & 81.10 & .26 \\
& Total & 80.48 & \\
\hline Progressive & No & 82.87 & .42 \\
& Yes & 85.67 & \\
& Total & 84.67 & .78 \\
Humanistic & No & 73.34 & \\
& Yes & 75.00 & \\
& Total & 74.41 & \\
\hline Radical & No & 68.97 & 68.30 \\
& Yes & 68.54 & \\
\hline \hline
\end{tabular}




\section{CHAPTER V}

\section{SUMMARY, CONCLUSIONS, AND RECOMMENDATIONS}

The purpose of this study was to increase understanding of adult education philosophies as practiced by secondary school agriculture teachers in Pennsylvania, West Virginia and Virginia.

\section{Methodology}

\section{$\underline{\text { Population }}$}

The population in this study consisted of all agricultural education teachers from Pennsylvania, West Virginia, and Virginia who taught classes and were listed in their state's Agricultural Education Directory for the 1998-1999 academic year. A sample size of 314 was needed to represent this population.

There were two groups used in this study. One group was composed of 93 adult educators and the second group was composed of 221 non-adult educators. A total of 118 usable surveys were returned out of the 314 sent out. The return rate was $38 \%$. In the adult educator group 75 of the 93 educators responded making their return rate $81 \%$. Non adult educators returned 43 of the 221 surveys sent out making their return rate $19 \%$.

\section{$\underline{\text { Design and Instrumentation }}$}

Descriptive survey methodology and correlational design were used in this study. Data were collected by mailed questionnaires. The questionnaire included a demographic sheet that asked the state that the educator teaches in, age, gender, highest degree obtained, total number of years teaching, if they teach adults, how long they have been adult educators, and do they receive payment for teaching adults.

The tool used to obtain the educators' philosophies was the Philosophy of Adult Education Inventory (PAEI). The PAEI contains five philosophical orientations. They are 
Liberal, Behaviorist, Progressive, Humanist, and Radical. The PAEI contains 75 Likert-type statements on a seven-point scale. On the scale, $1=$ strongly disagree, $4=$ neutral, and $7=$ strongly agree.

\section{Validity and Reliability of the Instrument}

The PAEI has been determined to be a valid and reliable instrument by Zinn and Wingenbach with reported Cronbach 's alpha levels of 0.75 and 0.86 , respectively. $\underline{\text { Data Collection }}$

Data collection started on May 7, 1999 with the sample being mailed a cover letter explaining the study, the demographic sheet, and the Philosophy of Adult Education inventory. Of the sample surveyed 118 (38\%) responses were received. Non-responses were dealt with using the double-dipped sample methodology and no differences were found to exist between respondents and non-respondents.

\section{$\underline{\text { Data Analysis }}$}

Data was analyzed using the Statistical Package for Social Sciences for Windows (SPSS). Descriptive statistics such as frequencies, means, and standard deviations as well as correlational and multivariate analyses were used to describe and analyze the research results.

\section{Summary and Conclusions}

The population of the study was the agricultural education teachers in Pennsylvania, West Virginia, and Virginia that taught classes during the 1998-1999 academic year. Data were collected on the following variables and the five philosophical orientations.

$\underline{\text { Age }}$

The average age of the respondents was 44 years. The youngest respondents being 22 years old and the oldest being 63 years of age. Using Pearson's Correlation low associations were found between age and the Liberal (.11) and Radical (.11) philosophies. The Behaviorist 
(.05), Progressive (.01), and Humanist (.00) philosophies showed negligible association to age. This indicates that age has no affect on philosophical orientations.

$\underline{\text { Total Years of Teaching }}$

The minimum years taught by the respondents was less that one year and the maximum was 35 years. The average years taught by the respondents were 19 years. Using Pearson's correlation a low association was found between years taught and the Liberal (.17) and Behaviorist (.17) philosophies. Negligible relationships were found between years taught and the Progressive (.06) and Radical (.04) philsophies while the progressive philosophy had a negative negligible association (-.03)to years taught. It can be concluded that years taught has no relationship on the educators' philosophical orientations.

$\underline{\text { Years of Teaching Adults }}$

The minimum years of teaching adults were one year while the maximum number of years of teaching adults was 34 years. The average years that educators had taught adults was 14 years. Pearson's correlation showed a low association between years of teaching adults and the Liberal (.15) and Radical (.13) philosophies. A Negligible relationship was shown to exist between the Behaviorist (.09) philosophy and years of teaching adults. Finally, negative negligible associations were found between the Progressive (-.04) and Humanist (-.01) philosophies and years of teaching adults. It can be concluded that there is no relationship between the years of teaching adults and the five philosophical orientations.

\section{$\underline{\text { Degree }}$}

This study was interested in whether the degree obtained by the educator had any influence on the educators' philosophical orientation. Out of the 118 respondents, $52(44.1 \%)$ had a Bachelors degree, $60(50.8 \%)$ had a Masters degree, and $1(.8 \%)$ had a PhD. Using Spearman's Rho correlation, there was a low association between the degree obtained and the 
Behaviorist (.10) and Progressive (.10) philosophies. There were negligible associations between the degrees obtained and the Liberal (.07), Humanist (.01), and Radical (.07) philosophies. It can be concluded that the degree obtained by the educator has no relationship with the five philosophical orientations.

Preparation for Teaching Adults

Respondents were asked if they received any education that pertained to teaching adults before they began teaching. Out of the 118 respondents, $62(52.5 \%)$ responded yes to receiving adult education preparation, $48(40.7 \%)$ of the respondents replied no, and $8(6.8 \%)$ did not answer this question. Using Spearman's Rho correlation, there was a low association between adult education preparation and the Behaviorist (.14), Humanist (.17), and Radical (.13) philosophies. Negligible associations existed between adult education preparation and the Liberal (.07), and Progressive (.05) philosophies. It can be concluded that there is a slight relationship between adult education preparation and the five philosophical orientations. $\underline{\text { State }}$

The states surveyed in this study were Pennsylvania, West Virginia, and Virginia. Out of the 118 respondents, $49(41.5 \%)$ were from Pennsylvania, 24 (20.3\%) were from West Virginia, and $45(38.1 \%)$ were from Virginia. Using Spearman's Rho correlation, the Behaviorist (-.02) and Radical (-.08) philosophies association to the state variable was negative negligible. Liberal (.00) and Progressive (.09) philosophies showed a negligible association to the state variable. The Humanist (-.27) philosophy showed a low negative correlation to the state variable. However, an Analysis of Variance (ANOVA) test showed that the Humanist philosophy was statistically significant to the .05 level when comparing the states of Pennsylvania and West Virginia. The Humanist philosophy did not show a significant relationship when Pennsylvania 
was compared to Virginia. This could account for the low correlation of state to the Humanist philosophy.

$\underline{\text { Gender }}$

Out of the 118 respondents, $99(83.9 \%)$ were male and 19 (16.1\%) were females. Using Spearman's Rho correlation, a negative negligible relationship was shown between the Behaviorist (-.05) and Humanist (-.02) philosophies and gender. There was a negligible association between the Liberal (.06) philosophy and the gender of the respondents. A low association was shown to exist between gender and the Progressive (.13) and Radical (.10) philosophies. It can be concluded that there is no relationship between the gender of the respondent and the five philosophical orientations. There also was no significant difference between gender and the philosophies with the ANOVA test. This response contradicts the studies done by Zinn and Wingenbach. They both had found that females tend to score higher on the Radical philosophy. Wingenbach did mention that graduates with teaching experience (12 years average) exerted more of a Progressive philosophy instead of a high Radical philosophy. The females in this study are graduates and have some experience in teaching and this may be why they did not score high with the Radical philosophy.

\section{$\underline{\text { Adult Education Payment }}$}

Some educators are paid to teach classes in agriculture to adults. Out of the 118 respondents to the study, $69(58.5 \%)$ were paid to teach adult classes $38(32.2 \%)$ were not paid to teach adult classes, and $11(9.3 \%)$ respondents did not answer this question. Using Spearman's Rho correlation, a negative negligible association was found between payment for teaching adult classes and the Radical (-.04) philosophy. The Behaviorist (.09) and Humanist (.07) philosophies both showed negligible associations with payment. Liberal (.10) and Progressive (.19) philosophies had low associations with educators receiving payment for teaching adult classes. 
However, the correlation of educators' payment with the Progressive philosophy was low but significant at the .05 level.

\section{$\underline{\text { Philosophical Correlation }}$}

Of the 118 surveys returned to the researcher no educators scored high in the Liberal Philosophy. The Progressive philosophy had 80 (67.8\%) high scores, the Behaviorist had 25 (21.2\%) high scores, Humanist philosophy had 9 (7.6\%) high scores, and the Radical philosophies had 4 (3.4\%) high scores. Using Pearson's correlation, the Liberal philosophy had a very strong association (.81) with the Behaviorist philosophy. The Progressive philosophy had a very strong association (.72) with the Behaviorist philosophy. A substantial relationship was found between the Liberal and Progressive philosophies (.59) and the Humanist and Progressive philosophies (.55). A moderate relationship was found between the Humanist and Radical philosophies (.48), the Humanist and Behaviorist philosophies (.42), Humanist and Liberal philosophies (.38), and the Behaviorist and Radical philosophies at (.30). There was a low association found between the Liberal and Radical philosophies (.29) and the Radical and Progressive philosophies (.26). A high score indicates that the educator most closely related their teaching with that philosophy. It is not uncommon for educators to score high for two philosophies because some of the philosophies overlap. Zinn (1994) indicates that to have a high score in Liberal and Behaviorist philosophies, Progressive and Humanistic, Progressive and Radical, or Humanistic and Radical is likely. Unlikely combinations would be Liberal and Radical and Behaviorist and Humanistic. 


\section{RECOMMENDATIONS}

Recommendations for further studies include:

1. Replicate this study in other geographical areas to determine if the philosophies are correlated with different regions.

2. A study to compare the teaching philosophies of educators when teaching both minors and adults. 


\section{BIBLIOGRAPHY}

Adelaine, Michael F. \& Foster, Richard M., (1989). Attitudes of Nebraska superintendents, principals, and vocational agriculture instructors regarding the delivery of adult education through secondary programs. Journal of Agricultural Education. 30 (1), 10-16.

Apps, J. W. (1981). The adult learner on campus: A guide for instructors and administrators. Chicago: Follett Publishing Company.

Apps, J. W. (1989). Foundations for effective teaching. In E. R. Hayes (Ed.), Effective teaching styles: New directions for continuing education, No. 43, Fall. (pp. 17-27). San Francisco: Jossey-Bass Inc., Publishers.

Ary, D., Jacobs, L., \& Razavieh, A. (1996). Introduction to Research in Education (5th ed.). Fort Worth: Harcourt Brace.

Beder, H. (1989). Purposes and philosophies of adult education. In S. B. Merriam and P.M. Cunningham (Eds.), Handbook of adult and continuing education. (pp. 37-48). San Francisco: Jossey-Bass Inc., Publishers.

Bender, R. E., McCormick, R. W., Woodin, R. J., Cunningham, C. J., \& Wolf, W. H. (1972). Adult education in agriculture. Columbus, Ohio: Charles E. Merrill.

Berger, P. \& T. Luckmann (1966). The social construction of reality. New York: Doubleday.

Birkenholz, Robert J. \& Maricle, Gary L., (1991). Adult education in agriculture: A National survey. Journal of Agricultural Education, 32 (4), 19-24.

Borg, Walter R. \&Gall, Meredith D. (1989). Educational research: An introduction (fifth edition). New York: Longman.

Bowen, B, \& Escolme, K. (1990). Computer education priorities of farmers. Journal of Agricultural Education, 31 (1), 39-45. 
Brockett, Ralph G. \& Merriam, Sharan B. (1997). The profession and practice of adult education: An introduction. San Francisco: Jossey-Bass Inc., Publishers.

Brostrom, R. (1979). Training style inventory. In J. E. Jones \& J. W. Pfeiffer (Eds.), The 1979 annual handbook for group facilitators (pp. 92-98). La Jolla: University Associates.

Chizari, Mohammed \& Taylor, Walter, (1991). Agriculture teachers' perceptions of adult education programs: an examination of critical educational needs, obstacles faced, and support needed. Journal of Agricultural Education. 32 (2), 23-28.

Darkenwald, G. \& Merriam, S. (1982). Adult Education: Foundations of Practice. New York, Harper and Row.

Ellias, J. \& Merriam, S. (1980). Philosophical foundations of adult education. Melbourne, Florida: Krieger Publishing Company.

Ford, Carey L., (1995). Educational priorities of small farmers in west Tennessee. Journal of Agricultural Education, 36 (1), (31-37).

Goodman, J. (1988). Constructing a practical philosophy of teaching: A study of preservice teachers' professional perspectives. Teaching \& Teacher Education, 4 (2), 121-137. Heimstra, R. (1991). Translating personal values and philosophy into practical action. In R.G. Brockett (Ed.), Ethical issues in adult education. New York: Teachers College Press.

Hellyer, Mickey R. \& Schulman Beth (1989). Worker's education. In S. B. Merriam and P.M. Cunningham (Ed.). Handbook of adult and continuing education. (pp. 569-582). San Francisco: Jossey-Bass Inc., Publishers.

Knowles, M. S. (1970). The Modern Practice of Adult Education. New York: Association Press.

Krejcie, Robert V. \& Morgan, Daryle W. (1970). Determining sample size for research activities. Educational and Psychological Measurement. 30, 607-610. 
Kussrow, Paul G. (1997). From Pedagogy through Andragogy to Holosagogy. (Eric Document Reproduction Service No. ED 412213).

McKenzie, L. (1985). Philosophical orientations of adult educators. Lifelong learning: An omnibus of practice and research, 9 (1), 18-20.

Merriam, S. B. (1982). Some thoughts on the relationship between theory and practice. In S. B. Merriam (Ed.), Linking philosophy and practice: New directions for adult and continuing education, No. 15. (pp. 90-91). San Francisco: Jossey-Bass Inc., Publishers.

Rachal John R., (1989). The social context of adult and continuing education. In S. B. Merriam and P. M. Cunningham (Ed.), Handbook of adult and continuing education. (pp. 3-14). San Francisco: Jossey-Bass Inc., Publishers.

Seevers, Brenda S., (1995). Extensionists as adult educators: A look at teaching style preference. Journal of Extension, 33 (3), gopher://joe.org/00/joe/1995june/rb2

Stensland Per G., (1955). What is adult education: Nine working definitions. Adult Education. Volume V, No. 3, 1-12.

Swanson, G. I. (1967). Philosophy for teacher education in agriculture. In A. L. Berkey (Ed.), Teacher education in agriculture. (pp. 287-288). Danville, Illinois: The Interstate Printers \& Publishers, Inc.

United States Department of Health, Education, and Welfare: Office of Education. (February 21, 1978). Vocational agriculture for yung farmers: preparing and conducting a program of instruction in vocational agriculture for young farmers. Washington, D.C.: Author.

Wingenbach, G. J. (1996, May). The philosophy of adult education inventory (PAEI) revisited. In W. Camp (Chair) Proceedings of the Eastern Region Agricultural Education Research Conference, 50, 67-74. 
Zinn, L. M. (1983). Development of a valid and reliable instrument for adult educators to identify a personal philosophy of adult education. Dissertation Abstracts International, 44, 1667A-1668A.

Zinn, L. M. (1990). Identifying your philosophical orientation. In M.W. Galbraith (Ed.), Adult learning methods. (pp. 39-56). Malabar, Florida: Krieger Publishing Company.

Zinn, L.M. (1994). Philosophy of adult education inventory, with forward (Rev. ed.). Boulder, CO: Lifelong Learning Options. 


\section{APPENDICES}




\section{APPENDIX A}

Cover Letter to Sample of Secondary Agricultural Teachers 
Dear Agriculture Teacher:

Congratulations on being selected in a random sample of secondary agriculture teachers from the states of Virginia, West Virginia, or Pennsylvania! I am conducting research for partial fulfillment of the requirements for a Master's of Science in Agricultural Education. Your valued participation in completing the enclosed survey may help us understand more about the adult education philosophies of Virginia, West Virginia, and Pennsylvania agriculture teachers.

The enclosed questionnaire is the Philosophy of Adult Education Inventory (PAEI) survey. Lorraine M. Zinn designed this survey for the purpose of helping educators discover their philosophies towards adult education. Also included is a sheet requesting your demographic information such as your teaching experience, gender, state residence, and educational status. You are asked to fill out the PAEI survey (15 questions) along with the demographic information sheet. Please respond to every question; if there are some questions that you cannot answer then please omit them. However, this will cause inaccurate scoring of the PAEI. Return the entire PAEI instrument and demographic sheet in the self-addressed stamped envelope immediately. Your responses will be kept confidential and only group responses will be reported from this research study. Upon receipt of your PAEI instrument, researchers will determine your appropriate adult education philosophy and report it back to you immediately. The code number listed on the PAEI is for follow-up mailing purposes only.

Your participation is completely voluntary, but remember that your response may be representative of the larger population of secondary agriculture teachers throughout Virginia, West Virginia, or Pennsylvania. The survey will take no longer than ten minutes to complete. If you would rather not participate in the study please mark the appropriate box on the demographic information sheet and return it in the self-addressed envelope. Thank you for your time and cooperation.

Sincerely,

Crystal R. Buckingham

Graduate Student

Agricultural and Environmental Education

Enc. 
APPENDIX B

Demographic Sheet 


\section{Philosophy of Adult Education I nventory}

\section{Demographic Information}

Check the state in which you are employed:

West Virginia

Virginia

Pennsylvania

Please record your age:

Age

What is your gender:

Male

Female

Place a check in the blank next to the highest degree you have achieved:

Bachelor's degree

Master's degree

Doctoral degree

Record the number of years you have taught secondary school students

Do you teach adults:

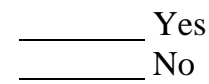

If yes, record the number of years you have taught adult classes

Did you receive formalized education courses in preparation for teaching adults?

Yes

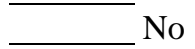

Do you receive payment for teaching adult classes?

Yes

No

Check here if you would rather not participate in this study

Thank you for completing this survey. Please enclose it in the self-addressed envelope and return it to Crystal Buckingham today. 


\section{APPENDIX C}

Philosophy of Adult Education Inventory (PAEI) 


\section{PHILOSOPHY OF ADULT \\ EDUCATION INVENTORY ${ }^{\odot}$}

(Revised, 1994)

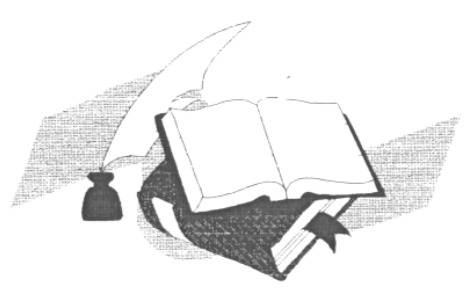

The Philosophy of Adult Education Inventory ${ }^{\complement}$ (PAEI) is an assessment instrument developed to assist the adult educator to identify his/her personal philosophy of education and to compare it with prevailing philosophies in the field of adult education. The PAEIC was designed to be self-administered, self-scored and selfinterpreted.

Validity and reliability test data are summarized in Dissertation Abstracts International, 44, 1667A-1668A (Zinn, 1983).

Copyright 1994 by Lorraine M. Zinn. All rights reserved. This material is not to be copied or disseminated without permission. Additional copies may be ordered from Lifelong Learning Options, 4757 West Moorhead Circle, Boulder, CO 80303-6157 or FAX 303499-7341. 


\section{APPENDIX D}

Cover Letter for PAEI Score Sheet and Philosophy Information Sheet 
Dear Agriculture Teacher,

Thank you for participating in the study of agriculture teachers' philosophies of adult education. I appreciate the time you took out of your schedule to complete the PAEI.

Enclosed with this letter are your PAEI scores indicating your philosophy of adult education and additional information explaining the five philosophical tenants used in this study. It is important to realize that the terms Liberal and Radical, as used in the study, are not meant in a political sense. A Liberal philosophy can be though of in the Classical or Traditional educational modality. An alternative term for the Radical Philosophy is more commonly referred to as the Reconstructionist viewpoint.

Sometimes it is difficult to take time out from "doing" adult education, in order to think about why you teach what you teach. However, a little effort in this direction from time to time can reap valuable benefits. Philosophizing about adult education will probably not make a philosopher out of you, but it might help you to be a better adult educator.

Sincerely,

Crystal R. Buckingham

Master's Candidate

Agricultural and Environmental Education

Enc. 


\section{APPENDIX E}

PAEI Score Sheet and Philosophy Information Sheet 


\begin{tabular}{|c|c|c|c|c|c|}
\hline \multicolumn{6}{|c|}{ FIVE PHILOSOPHIES OF ADULT EDUCATION } \\
\hline $\begin{array}{l}\text { TOTAL } \\
\text { SCORES }\end{array}$ & $L=$ & $\mathbf{B}=$ & $P=$ & $\mathbf{H}=$ & $\mathbf{R}=$ \\
\hline & $\begin{array}{l}\text { LIBERAL (ARTS) } \\
\text { ADULT EDUCATION }\end{array}$ & $\begin{array}{l}\text { BEHAVIORAL } \\
\text { ADULT EDUCATION }\end{array}$ & $\begin{array}{l}\text { PROGRESSIVE } \\
\text { ADULT EDUCATION }\end{array}$ & $\begin{array}{c}\text { HUMANISTIC } \\
\text { ADULT EDUCATION }\end{array}$ & $\begin{array}{c}\text { RADICAL } \\
\text { ADULT EDUCATION }\end{array}$ \\
\hline PURPOSE(S) & $\begin{array}{l}\text { To develop intellectual } \\
\text { powers of the mind; to } \\
\text { enhance the broadest } \\
\text { sense of learning; to } \\
\text { provide a general, "well- } \\
\text { rounded" education. }\end{array}$ & $\begin{array}{l}\text { To promote competence, } \\
\text { skill development and } \\
\text { behavioral change; ensure } \\
\text { compliance with } \\
\text { standards and societal } \\
\text { expectations. }\end{array}$ & $\begin{array}{l}\text { To support responsible } \\
\text { participation in society; to } \\
\text { give learners practical } \\
\text { knowledge and problem- } \\
\text { solving skills. }\end{array}$ & $\begin{array}{l}\text { To enhance personal } \\
\text { growth and development; } \\
\text { to facilitate individual self- } \\
\text { actualization. }\end{array}$ & $\begin{array}{l}\text { To bring about, through } \\
\text { education, fundamental } \\
\text { social, cultural, political, } \\
\text { and economic changes in } \\
\text { society. }\end{array}$ \\
\hline LEARNER(S) & $\begin{array}{l}\text { "Renaissance person"; } \\
\text { always a learner; seeks } \\
\text { knowledge; expected to } \\
\text { gain and conceptual and } \\
\text { theoretical understanding. }\end{array}$ & $\begin{array}{l}\text { Learners not involved in } \\
\text { setting objectives; master } \\
\text { one step before another; } \\
\text { practice behaviors/skills } \\
\text { to get them right. }\end{array}$ & $\begin{array}{l}\text { Learner needs, interests, and } \\
\text { experiences are valued and } \\
\text { become part of learning } \\
\text { process; learner takes an } \\
\text { active role in learning. }\end{array}$ & $\begin{array}{l}\text { Learner is highly motivated } \\
\text { and self-directed; assumes } \\
\text { responsibility for learning; } \\
\text { very involved in planning } \\
\text { learning projects. }\end{array}$ & $\begin{array}{l}\text { Learner and "teacher" are } \\
\text { equal in learning process; } \\
\text { personal autonomy; } \\
\text { learner is empowered; } \\
\text { voluntary participant.. }\end{array}$ \\
\hline $\begin{array}{l}\text { TEACHER } \\
\text { ROLE }\end{array}$ & $\begin{array}{l}\text { The "expert"; transmitter of } \\
\text { knowledge; teaches } \\
\text { students to think; clearly } \\
\text { directs learning process. }\end{array}$ & $\begin{array}{l}\text { Manager, controller; } \\
\text { authoritative; sets } \\
\text { expectations; predicts and } \\
\text { directs learning outcomes. }\end{array}$ & $\begin{array}{l}\text { Organizer; guides learning } \\
\text { process; provides real-life } \\
\text { learning applications; helps } \\
\text { learners work cooperatively. }\end{array}$ & $\begin{array}{l}\text { Facilitator; helper; mutual } \\
\text { participant in teaching- } \\
\text { learning exchange; } \\
\text { supports learning process. }\end{array}$ & $\begin{array}{l}\text { Coordinator; convener; } \\
\text { equal partner with learner; } \\
\text { suggests but does not } \\
\text { determine directions. }\end{array}$ \\
\hline $\begin{array}{l}\text { CONCEPTSI } \\
\text { KEY WORDS }\end{array}$ & $\begin{array}{l}\text { Liberal arts; learning for its } \\
\text { own sake; general and } \\
\text { comprehensive education; } \\
\text { critical thinking; traditional } \\
\text { knowledge; academic } \\
\text { excellence. }\end{array}$ & $\begin{array}{l}\text { Standards-based; } \\
\text { mastery learning; } \\
\text { competence; behavioral } \\
\text { objectives; performance; } \\
\text { practice, } \\
\text { feedback/reinforcement; } \\
\text { accountability. }\end{array}$ & $\begin{array}{l}\text { Problem-solving; practical } \\
\text { learning; experience-based; } \\
\text { needs assessment; transfer } \\
\text { of learning; active inquiry; } \\
\text { collaboration; social } \\
\text { responsibility. }\end{array}$ & $\begin{array}{l}\text { Freedom; autonomy; } \\
\text { individuality; teaching- } \\
\text { learning exchange; self- } \\
\text { directedness; interpersonal } \\
\text { communication; openness; } \\
\text { authenticity; feelings. }\end{array}$ & $\begin{array}{l}\text { Consciousness-raising; } \\
\text { praxis; noncompulsory } \\
\text { learning; autonomy; social } \\
\text { action; empowerment; } \\
\text { social justice; } \\
\text { commitment; } \\
\text { transformation. }\end{array}$ \\
\hline METHODS & $\begin{array}{l}\text { Lecture; reading and } \\
\text { critical analysis; question- } \\
\text { and-answer; teacher-led } \\
\text { discussion; individual } \\
\text { study; standardized } \\
\text { testing. }\end{array}$ & $\begin{array}{l}\text { Computer-based } \\
\text { instruction, lock-step } \\
\text { curriculum, skill training, } \\
\text { demo \& practice, } \\
\text { criterion-referenced } \\
\text { testing. }\end{array}$ & $\begin{array}{l}\text { Projects; scientific or } \\
\text { experimental method; } \\
\text { simulations; group } \\
\text { investigation; cooperative } \\
\text { learning; portfolios. }\end{array}$ & $\begin{array}{l}\text { Experiential learning; } \\
\text { discovery learning; open } \\
\text { discussion; individual } \\
\text { projects; collaborative } \\
\text { learning; independent } \\
\text { study; self-assessment. }\end{array}$ & $\begin{array}{l}\text { Critical discussion and } \\
\text { reflection; problem-posing; } \\
\text { analysis of media output; } \\
\text { social action theater. }\end{array}$ \\
\hline $\begin{array}{l}\text { PEOPLE \& } \\
\text { PRACTICES }\end{array}$ & $\begin{array}{l}\text { Aristotle, Plato, Adler, } \\
\text { Rousseau, Piaget, Houle, } \\
\text { Great Books Society, } \\
\text { Paideia Program, Center } \\
\text { for the Study of Liberal } \\
\text { Education, Chautauqua, } \\
\text { Elderhostel. }\end{array}$ & $\begin{array}{l}\text { Thorndike, Watson, } \\
\text { Skinner, Tyler, Mager, } \\
\text { vocational training, } \\
\text { management-by- } \\
\text { objectives, certification } \\
\text { exams, military training, } \\
\text { religious indoctrination. }\end{array}$ & $\begin{array}{l}\text { Dewey, Whitehead, } \\
\text { Lindeman, community } \\
\text { college developmental } \\
\text { studies, citizenship } \\
\text { education, cooperative } \\
\text { extension, university without } \\
\text { walls, community schools. }\end{array}$ & $\begin{array}{l}\text { Rogers, Maslow, Knowles, } \\
\text { Tough, group dynamics, } \\
\text { self-directed learning, I'm } \\
\text { OK, You're OK; diversity } \\
\text { education, credit for prior } \\
\text { learning. }\end{array}$ & $\begin{array}{l}\text { Holt, Freire, Illich, Kozol, } \\
\text { Shor, Ohliger, Perelman, } \\
\text { free school movement, } \\
\text { Afro-centrism, voter } \\
\text { registration/education, } \\
\text { social justice education. }\end{array}$ \\
\hline
\end{tabular}




\section{WHAT YOUR SCORES INDICATE}

$L=$ LIBERAL (ARTS) ADULT EDUCATION

(Education for Intellectual Development;

General Education for Life)

$B=$ BEHAVIORAL ADULT EDUCATION

(Education for Competence, Behaviora

Change, Compliance with Standards)

$P=$ PROGRESSIVE ADULT EDUCATION

(Education for Practical Problem Solving)

$\mathrm{H}=$ HUMANISTIC ADULT EDUCATION

(Education for Individual Self-Actualization)

$R=$ RADICAL ADULT EDUCATION

(Education for Transforming Society)

\section{WHAT IS A PHILOSOPHY OF EDUCATION?}

A Philosophy of Education represents a comprehensive and interrelated set of values and beliefs as applied to education -

including beliefs about the purpose and nature of human life, the role of the individual in society, purposes or goals of education, role(s) of teachers and students, important subject matter, and effective teaching approaches.

An educational philosophy is much broader than a preference for specific teaching methods - although preferred teaching techniques are usually consistent with the educational philosophy. However, teaching techniques most characteristic of one philosophy may be used selectively by a teacher who has a different educational philosophy. Educational philosophies are fairly deeply held, closely aligned with people's life values, and unlikely to change significantly Teaching techniques or teaching style, however, may vary

depending on what works best in a particular situation, as long as the techniques used are not incompatible with basic premises of a teacher's philosophy of education.
On the next page, you will find brief descriptions of these five Philosophies of Adult Education. * You may want to write your score for each Philosophy above the column that describes it. Your highest score reflects the Philosophy that is closest to your own beliefs; your lowest score reflects a Philosophy that is least like yours. For example, a score of 90-105 indicates that you very strongly agree with that Philosophy; a score of 25 or lower indicates that you very strongly disagree with a given Philosophy. NOTE: If you find your scores fairly equal among all of the Philosophies, or spread among three or more, you may want to spend some time further clarifying your beliefs and values and looking for possible contradictions among them.

Most Adult Educators have a clear primary philosophical orientation or share two that are stronger than others. Typical combinations are: LIBERAL (ARTS) and BEHAVIORAL,

PROGRESSIVE and HUMANISTIC, PROGRESSIVE and RADICAL, or HUMANISTIC and RADICAL. On the other hand, it is quite unlikely that you would have high scores in both Liberal (ARTS) and RADICAL, or BEHAVIORAL and HUMANISTIC Philosophies. These philosophies have key underlying assumptions that are inherently contradictory. (For example, the primary purpose of Behavioral Education is to ensure compliance with expectations or standards set by others; while Humanistic Education is intended to enhance individual self-development - which may or may not meet anyone else's expectations or standards.)

There is no right or wrong Philosophy of Adult Education. The Philosophy of Adult Education Inventory $($ ) is designed to reflect back to you some of your own beliefs, not to make judgments about those beliefs. It is up to you to decide how your beliefs may influence your decisions and actions as an educator, and how your personal educational philosophy may be well-suited, or perhaps not the best match, for the educational setting in which you work.

* Descriptions adapted from J. Elias and S. Merriam (1995),

Philosophical Foundations of Adult Education (2nd. ed.), Krieger. 
APPENDIX F

Two-Week Follow-Up Letter to Non-Respondents 
Dear Agriculture Teacher,

Two weeks ago, I sent you a survey for a tri-state study regarding the philosophies of adult educators. Your name was drawn in a random sample from the Virginia, West Virginia, and Pennsylvania state Agriculture Teacher Directories.

If you have already completed and returned it to me, please accept my sincere thanks. If not, this is a reminder to please do so today. I sent this questionnaire to a small number of teachers in the tri-state area. It is extremely important that your results be included in the study so they can better represent all agriculture teachers in this region. I appreciate you taking a few minutes to complete the Philosophy of Adult Education Inventory and demographic sheet and return it today.

If you did not receive the PAEI survey, or it was misplaced, please call (304) 293-4832, ext. 4481 (Mon.-Fri.) and leave a message or email my professor at gwingenb@wvu.edu. I will be happy to send you another copy. Thanks!

Sincerely,

Crystal R. B uckingham 


\section{APPENDIX G}

Four-Week Follow-Up Letter to Non-Respondents 
Dear Agriculture Teacher,

Four weeks ago, I sent you a survey from a tri-state study regarding the philosophies of adult educators. Your name was drawn in a random sample from the Virginia, West Virginia, and Pennsylvania State Agriculture Teacher Directories.

I have received responses to the survey from many of your colleagues. However, my records show that I have not received your survey. If you have already completed it and returned it to me, please accept my sincere thanks. If not, please do so today. I sent this questionnaire to a small number of teachers in the tri-state area. It is important that your results are included for an accurate representation of all agriculture teachers in this region. PLEASE complete the Philosophy of Adult Education Inventory and demographic sheet, and return it today.

If you did not receive the PAEI survey, or it was misplaced, please call (304) 293-4832, ext. 4481 (Mon.-Fri.) and leave a message or email my professor at gwingenb@wvu.edu. I will be happy to send you another copy. Thanks!

Sincerely,

Crystal R. Buckingham 
APPENDIX $\mathrm{H}$

Cover Letter to Sample Non-Respondents for Double Dip Methodology 
Dear Agriculture Teacher,

Five weeks ago, you were sent a survey concerning agriculture teachers' philosophies of adult education. This tri-state study involving agriculture teachers from Pennsylvania, West Virginia, and Virginia, may help us understand more about adult education philosophies in these states.

I did not receive your survey to date. Since I have not received your initial PAEI instrument, please find enclosed another PAEI, which can be used to record your philosophical beliefs about educating adults. Again, your responses may represent a much larger population of agriculture teachers in the tri-state region. It is imperative that I receive your responses today. The survey will take no longer than $\mathbf{1 0}$ minutes to complete. Thank you for your time and cooperation.

Sincerely,

Crystal R. Buckingham

Master's Candidate

Agriculture and Environmental Education

Enc. 